\title{
Bird Migration Collision Casualties at Saskatoon
}

by Michael A. Gollop, Saskatoon

Mass casualties of birds migrating at night in the spring and fall have been the subject of a number of articles in recent issues of the Blue Iay (17:142-143, 19:160-164, 20:151-152, $20: 152)$. This is the first detailed report on birds colliding with radio and TV towers and power lines during migration at Saskatoon. This paper deals mainly with birds found during the 1964 southward migration season but also includes some data on spring and fall kills from 1961 to 1963.

Irregular checks for bird kills at most of the structures listed in Table 1 yielded the following results: 32 dead birds in 1961, 74 in 1962, 17 in 1963, and 420 in 1964. The dates that various structures were checked in 1964 and the numbers of birds found (in parentheses) is as follows:

CFQC-TV: May 4 (24), May 8 (1 Savannah Sparrow), August 13 (1 Blackpoll Warbler), August 23 (110), August 25 (1 Ovenbird), September 4 (192), September 6 (16), September 7 (9), September 8 (2), September 10 (2), September 13 (4), September 19 (4), September 26 (0), September 29 (1 LeConte's Sparrow, October 3, (1 Lapland Longspur), October $10(0)$; CKOM: August 11 (1 Ruddy Duck), August 21 (0), September 5 (19); CFNS: September 5 (11); RCMP: September 5 (5); CFQC Radio: September 5 (1 Blackpoll Warbler); Hague Communication Relay Tower: May 9 1; Sandbar: August 12 (2), August 14 (3), August 15 (2), August 16, 17, $18,20(0)$, August 21 (1), August 22 (0), September 4 (2), October 4 (2), October 10 (3). (All the birds found dead on a particular day did not necessarily die on one night.) The three largest 1964 kills occurred at the TV antenna: 24 birds were found on May 4, 110 on August 23, and 191 on September 4. Species found on these three dates and the totals for all years are shown in Table 2; species found at the Power Lines-Sandbar site are discussed later.

Our procedure was for one to four people to go around each tower beginning at the base of the farthest guy wires and making two or three complete circles before reaching the base of the tower. Depending on results we might then check beyond the guy wires. If this was done it almost always involved only the south and east sides of the tower. The farthest we ever found a bird from a structure was $750 \pm$ feet; this was a Yellow Warbler which was found at the TV tower on September 6 after a night of high winds. The following people assisted in the project in 1964: Michael Gollop (on 24 dates and 25 hours), J. B. Gollop (18, 18), Robert Tomczak $(5,3.5)$, Dr. W. J. Maher (3, 3.5), Robert Busch $(1,2)$, W. A. Benson and R. Jakimchuk ( $1,0.50$ each). Common names of birds used in this paper follow the A.O.U. Check-list of North American Birds (1957). Identification was by the author based mainly on $T$. S. Roberts' "A Manual for the Identification of the Birds of Minnesota and Neighboring States" (U. Minn. Press, Minneapolis, 1955), with some assistance from Dr. C. S. Houston and J. B. Gollop.

It is worthwhile attempting to relate

Table 1 - Physical data on more important structures checked at Saskatoon, 1961-1964

\begin{tabular}{|c|c|c|c|c|c|}
\hline Structure & & $\begin{array}{c}\text { Location } \\
\text { (S-Twp-R-Mer) }\end{array}$ & $\begin{array}{c}\text { Altitude } \\
\text { of Bose } \\
\text { (feet above } \\
\text { sea level) } \\
\end{array}$ & $\begin{array}{l}\text { Height } \\
\text { of } \\
\text { Structure } \\
\text { (feet) }\end{array}$ & $\begin{array}{l}\text { Total } \\
\text { Length } \\
\text { of Guy } \\
\text { Wires } \\
\text { (feet) }\end{array}$ \\
\hline CFQC-TV & 1 tower & SE 20-37-3 w3 & $1,975 \pm$ & 650 & 8,300 \\
\hline RCMP & 1 tower & SE $5-37-3$ w3 & $1,825 \pm$ & 300 & 1,570 \\
\hline CFNS & 3 towers & NE $19-36-4$ w3 & $1,670 \pm$ & 250 & 10,000 \\
\hline CKOM & 4 towers & NE $\quad 9-36-4$ w3 & $1,675 \pm$ & $\begin{array}{l}1-350 \\
3-150\end{array}$ & $\begin{array}{l}3,800 \\
3,200\end{array}$ \\
\hline Power Lines & 29 wires & SE $18-36-6$ w3 & $\underset{\text { (River) }}{1,550} \pm$ & $50-75$ & $9,500 \pm$ \\
\hline
\end{tabular}


T.able 2 -Collision casualties recorded at Saskatoon, 1961-1964

\begin{tabular}{|c|c|c|c|c|c|c|c|c|c|}
\hline \multirow[b]{2}{*}{ Species } & \multicolumn{4}{|c|}{$\begin{array}{l}\text { Totals For } \\
\text { All Structures }\end{array}$} & \multicolumn{3}{|c|}{ TV Towers 1964} & \multicolumn{2}{|c|}{$\begin{array}{c}\text { Aug. } 12- \\
\text { Ort. } 10 \\
1964 \\
\text { All Structures }\end{array}$} \\
\hline & 1961 & 1962 & 1963 & 1964 & May 4 & Aug. 23 & Sept.4 & $\begin{array}{l}\text { No. } \\
\text { Birds }\end{array}$ & $\mid \begin{array}{c}\text { No. } \\
\text { Dates }\end{array}$ \\
\hline Western Grebe & 1 & - & - & - & - & - & - & 一 & \\
\hline Pied-billed Grebe - & -1 & - & 一 & 1 & 一 & 一 & 1 & 1 & 1 \\
\hline $\begin{array}{l}\text { Green-winged Teal } \\
\text { Blue-winged Teal }\end{array}$ & 1 & 二 & 二 & 1 & 二 & 二 & $\overline{1}$ & $\overline{1}$ & \\
\hline Ruddy Duck & 一 & 一 & 一 & 1 & - & 一 & 一 & $i$ & \\
\hline $\begin{array}{l}\text { Sparrow Hawk --- } \\
\text { Sora }\end{array}$ & $\overline{2}$ & $\overline{2}$ & 二 & 27 & 二 & $\overline{1}$ & & $\begin{array}{r}1 \\
27\end{array}$ & \\
\hline American CQot & 4 & 二 & - & 1 & 1 & 一 & - & 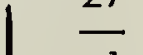 & 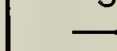 \\
\hline Common Snipe & - & 一 & - & 1 & 一 & - & 一 & 1 & 1 \\
\hline $\begin{array}{l}\text { Baird's Sandpiper } \\
\text { Semipalmated Sandpiper }\end{array}$ & 二 & 二 & $\underline{1}$ & 1 & 二 & 二 & 二 & 1 & \\
\hline Northern Phalarope & - & 一 & 二 & $i$ & - & 1 & - & 1 & 1 \\
\hline Rock Dove & 一 & 一 & 1 & 7 & 一 & - & - & & \\
\hline Yellow-shafted Flicker ... & 一 & - & - & 1 & 一 & 一 & 一 & 1 & 1 \\
\hline $\begin{array}{l}\text { Yellow-bellied Flycatcher } \\
\text { Traill's Flvcatcher }\end{array}$ & - & 1 & $\bar{l}$ & 二 & - & 二 & 二 & 二 & 二 \\
\hline Unidentified Empidonax & 二 & 二 & 1 & 26 & 二 & $\overline{19}$ & 4 & 26 & 4 \\
\hline House Wren & 二 & 2 & 一 & $\overrightarrow{1}$ & 一 & 二 & 工. & & \\
\hline $\begin{array}{l}\text { Long-billed Marsh Wren } \\
\text { Catbird }\end{array}$ & 二 & 一 & 二 & 1 & 二 & $=$ & 1 & 1 & \\
\hline Swainson's Thrush & - & 22 & 2 & 48 & 4 & $8^{*}$ & 31 & 44 & \\
\hline $\begin{array}{l}\text { Gray-cheeked Thrush } \\
\text { Veery }\end{array}$ & 二 & $\underline{2}$ & 二 & $\begin{array}{l}2 \\
3\end{array}$ & 1 & 二 & $\begin{array}{l}1 \\
3\end{array}$ & $\begin{array}{l}1 \\
3\end{array}$ & \\
\hline Unidentified Thrush & 1 & 2 & 二 & 2 & 1 & 1 & - & 1 & 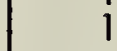 \\
\hline Ruby-crowned Kinglet & 1 & 二 & 二 & $\vec{a}$ & 二 & 二 & - & - & \\
\hline $\begin{array}{l}\text { Solitary Vireo } \\
\text { Red-eyed Vireo }\end{array}$ & 二 & $\overline{11}$ & 二 & $\begin{array}{r}4 \\
67\end{array}$ & 二 & $8^{*}$ & 50 & 67 & \\
\hline Black-and-white Warbler & - & 2 & - & 9 & 1 & 6 & 1 & 8 & \\
\hline see Warbler & 一 & 一 & 1 & 12 & 一 & 3 & 4 & 12 & \\
\hline $\begin{array}{l}\text { Ile Warbler } \\
\text {-crowned Warbler }\end{array}$ & $\overline{1}$ & 二 & 二 & 1 & 二 & 二 & 1 & 1 & \\
\hline Yellow Warbler & - & 1 & - & 20 & - & 13 & 5 & 20 & \\
\hline Magnolia Warbler & 1 & 一 & - & 5 & - & 3 & 2 & 5 & 2 \\
\hline $\begin{array}{l}\text { Myrtle Warbler } \\
\text { Black-throated Green Warbler }\end{array}$ & 2 & 二 & 二 & 1 & 二 & 1 & 二 & 1 & \\
\hline Bay-breasted Warbler & - & - & 一 & 2 & - & 一 & 1 & & 2 \\
\hline $\begin{array}{l}\text { Backpoll Warbler } \\
\text { Palm Warbler }\end{array}$ & $\overline{1}$ & 4 & 1 & $\begin{array}{r}14 \\
7\end{array}$ & 二 & 二 & $\begin{array}{r}10 \\
4\end{array}$ & $\begin{array}{r}14 \\
7\end{array}$ & $\begin{array}{l}4 \\
3\end{array}$ \\
\hline Ovenbird Warthern Warthrush & 1 & 5 & 2 & 33 & 7 & 12 & $\begin{array}{l}16 \\
3\end{array}$ & 33 & $\begin{array}{l}6 \\
4\end{array}$ \\
\hline Connecticut Warbler & - & - & 1 & & - & & & & \\
\hline Mourning Warbler & - & 1 & - & 11 & - & 7 & 1 & 11 & \\
\hline & 1 & $\sqrt{2}$ & 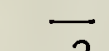 & 3 & 一 & $\overline{7}$ & 一 & 3 & \\
\hline $\begin{array}{l}\text { Warbler } \\
\text { Warbler }\end{array}$ & 2 & 3 & 2 & 11 & 二 & 7 & 二 & 11 & 4 \\
\hline 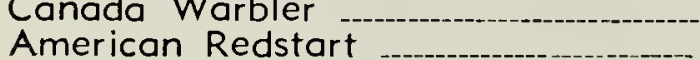 & - & 1 & 二 & 8 & 二 & 5 & $\overline{2}$ & $\begin{array}{l}1 \\
8\end{array}$ & 3 \\
\hline Unidentified Warblers & 3 & 4 & 一 & 10 & & 1 & 6 & 10 & 4 \\
\hline Western Meadowlark & 二 & 二 & 1 & 3 & - & ]$^{*}$ & $\overrightarrow{2}$ & 3 & \\
\hline Brewer's Blackbird & $T$ & 二 & 二 & - & 二 & - & 2 & 3 & \\
\hline annah Sparrow & 2 & - & 一 & 7 & 1 & - & 3 & 5 & \\
\hline ite's Sparrow & - & - & $\overline{1}$ & 2 & 一 & 二 & 一 & 2. & 2 \\
\hline $\begin{array}{l}\text { Vesper sparrow } \\
\text { Slate-colored Junco }\end{array}$ & 1 & 二 & $\underline{1}$ & 二 & 二 & 二 & 二 & 二 & E \\
\hline Tree Sparrow & & 一 & - & 2 & 1 & 一 & 一 & 1 & \\
\hline White-throated Sparrow & 1 & 1 & 一 & 6 & 2 & 一 & 2 & 4 & \\
\hline $\begin{array}{l}\text { Lincoln's Sparrow } \\
\text { Swamp Sparrow }\end{array}$ & 二 & - & 二 & $\begin{array}{r}16 \\
5\end{array}$ & 二 & 二 & 1 & $\begin{array}{r}16 \\
5\end{array}$ & $\begin{array}{l}5 \\
4 \\
-15\end{array}$ \\
\hline Song Sparrow & - & 1 & - & 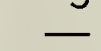 & - & - & - & 2 & \\
\hline Lapland Longspur - & 一 & - & - & 3 & 2 & 一 & - & 1 & 1 \\
\hline $\begin{array}{l}\text { Snow Bunting } \\
\text { Unidentified Sparrows }\end{array}$ & 1 & 1 & 7 & $\begin{array}{l}3 \\
3\end{array}$ & $\underline{3}$ & 二 & 二 & 3 & \\
\hline Unidentified Birds & 3 & - & - & 6 & 一 & 1 & 1 & 5 & 4 \\
\hline TOTAL & 32 & 74 & 17 & 420 & 24 & 110 & 191 & 394 & 26 \\
\hline
\end{tabular}

*Each asterisk represents a bird probably killed on a date different from the remainder of the column. 
weather conditions to major collisions but this is not always possible because weather information is usually recorded some distance from the site of the kill; in the following cases 12 miles west of CFQC-TV. Overnight weather on August 20-21, the date on which 106 of the birds picked up on August 23 were killed, was as follows: the wind was NNW. at 6-8 m.p.h. from 10:00 p.m., C.S.T., until midnight, and N. at 10-13 m.p.h. until 4:00 a.m. The temperature dropped from $56^{\circ} \mathrm{F}$ to $54^{\circ} \mathrm{F}$. There was 0.5 inches of rain between 6:00 p.m. and midnight, with an overcast ceiling dropping from 4,600 feet to 2,500 feet, then rising to 4,800 feet at one hour intervals beginning at 10:00 p.m. Between midnight and 4:00 a.m. there was one two-minute shower with broken layers of clouds at 5,000 feet and 10,000 feet. On September 34 , when at least 190 birds were killed, the wind was NW from 12 to 17 m.p.h. between 10:00 p.m. and 4:00 a.m. The temperature was $51^{\circ} \mathrm{F}$. from 10:00 p.m. until 2:00 a.m. and then it dropped to $45^{\circ} \mathrm{F}$. Cloud cover gradually increased from 0.8 at 10:00 p.m. to overcast at 1:00 a.m.; an hour later it was still overcast but by 3:00 a.m. it was only 0.1 . Cloud altitude varied from 7,000 to 8,000 feet. There was no precipitation.

Near the south side of the city, a series of power lines crossed a large sandbar where it was $110 \pm$ yards wide and attached to the east bank of the South Saskatchewan River. The Power Lines-Sandbar site presents an unusual picture and has been treated separately. It is our impression that birds found dead in this situation may reflect more accurately than the tower kills the migration pattern for the region. Inasmuch as the 29 wires are from 50 to 75 feet above the river, and since kills generally occurred under clear skies and almost completely unlikely conditions, it seems that birds must be attracted by reflections of light off the river and thus are flying low enough to be in danger from these wires. It is of interest to note that the dates on which birds were killed at this site generally represent a time of low ebb at the TV tower, e.g., October 10, TV-0, Sandbar-3, and vice versa, e.g., August 23 at TV-110, August 21 at Sandbar-1. Following are the records of kills at the Power Lines-Sandbar site: Baird's Sandpiper, August 14, 1;
Semipalmated Sandpiper, August 15, 1; Common Snipe, August 15, 1; Empidonax Flycatcher, August 12, 1; Swainson's Thrush, October 4, 1; Mourning (?) Warbler, August 12, 1; Wilson's Warbler, August 14, 1; Yellowthroat, September 4, 1; American Redstart, August 21, 1; Savannah Sparrow, October 10, 2; Tree Sparrow, October 4, 1; Lincoln's Sparrow, September 4, 1 and October 10, 1; unidentified bird, Auguist 14, 1 (total15 birds of 12 species).

Collision mortalities help to form an idea of bird movements and species composition. In addition, the time spent in checking kill sites may provide an opportunity to record live birds, e.g., we compiled a list of 67 species of birds while checking the Sandbar site, and 53 species over the past four years while checking the other sites. Observations of other animals may also result from such studies. For example, we found a Red Bat on September 19, 1964, at the TV tower, and on August 15, 1964, we photographed fresh tracks of a moose at the Sandbar site. Although our methods of checking for collision mortalities may be inefficient we feel that the time spent is worthwhile in view of the resulting information. In the future we hope to refine our techniques and thus obtain more information about this little known field.

\section{Acknowledgements:}

The author appreciates the assistance of Dr. R. W. Nero in writing this paper and of J. B. Gollop in compiling the data. The Meteorological Office, Department of Transport, Saskatoon, kindly supplied weather information. Most technical data on towers was supplied by RCA Victor of Montreal, Ajax Engineers Ltd. of Toronto, Station CFNS and the RCMP.

\section{PIGEON HAWK ARTICLE}

We wish to point out that the article on the Pigeon Hawk by Glen A. Fox (Blue Jay, 22:140-147) was mistitled by us. Falco columbaris richardsonii is not the most western race; $F$. c . bendirei breeds from northwestern Alaska, south to California and Idaho, and east to northern Saskatchewan. Richardsonii, the race in question, often called Richardson's Merlin, is primarily an arid plains form.-Ed. 